\title{
PENINGKATAN KUALITAS PERTUMBUHAN DAN KELANGSUNGAN HIDUP BENIH GURAMI (Osphronemus gouramy) MELALUI PERENDAMAN TIROKSIN ( $\left.\mathbf{T}_{4}\right)$

\author{
Ai Setiadi , Armen Nainggolan ${ }^{2}$, Ediyanto ${ }^{3}$ \\ 1) Lab. Lingkungan Kampus Sekolah Tinggi Perikanan (STP) Jakarta \\ ${ }^{2,3)}$ Fakultas Perikanan dan Ilmu Kelautan, Universitas Satya Negara Indonesia
}

\begin{abstract}
The aim of this research are to identify the impact and the optimal dosage of Tiroksin hormon for not only the growth but also thelife sustainability of Gurami fish. The origin of the fish is Tasikmalaya, in west Java. A jar shaped in tube 5 liters volume is the container that has been used for this research and contained polietilene (PE). The amount of the fish that has been used were 5 fishes per liter in size of $18 \mathrm{~mm}$ averagely, therefore each container was fulled by 20 fishes. The type of treatment was tiroksin hormon but only different dosage for each treatment. First treatment (D0) was as the control without giving the tiroksin hormon, second treatment (DI) contained $0.25 \mathrm{mg}$ dosage/liter, third treatment (D2) contained $0.5 \mathrm{mg}$ dosage/liter \& fourth contained (D3) $0.75 \mathrm{mg}$ dosage/liter, there were four times repetation for each. The weft given was tubifex worm in secheduled every morning at 7.00 and afternoon at 15.00 oclock. The ovserved parameter was the growth which were size and length, proksimat test and water quality. The result showed that the impact of tiroksin hormone produce the best treatment towards the feed of gurame fish this is on the fourth treatment, which were added by $0.75 \mathrm{mg}$ dosage/liter conduce $20.3 \pm 1.5 \mathrm{~mm}$ for the growing length, the growth $5.4 \pm 0.2 \mathrm{gr}$ and the subsainability was $0.88 \%$.
\end{abstract}

Keyword : Gurami (Osphronemus gouramy) Tiroksin (T4), Sintasan.

\begin{abstract}
Abstrak
Penelitian ini bertujuan untuk mengetahui efek serta dosis optimal hormon tiroksin terhadap pertumbuhan dan kelangsungan hidup benih ikan gurami. Ikan uji yang digunakan berasal dari Kota Tasikmalaya, Jawa Barat. Wadah yang digunkan adalah toples yang berbentuk tabung dari bahan polietilene (PE) dengan volume 5 liter. Jumlah padat tebar ikan yang digunakan adalah 5 ekor/l dengan ukuran ikan rata-rata $18 \mathrm{~mm}$, sehingga setiap wadah budidaya di isi sebanyak 20 ekor/wadah. Jenis perlakuan yang digunakan berupa hormon tiroksin dengan perbedaan pemberian dosis pada setiap perlakuan. Perlakuan 1 (D0) sebagai kontrol atau tanpa pemberian hormon tiroksin, perlakuan 2 (D1) dengan dosis $0,25 \mathrm{mg} / \mathrm{liter}$, perlakuan 3 (D2) dengan dosis 0,5 mg/liter dan perlakuan 4 (D3) dengan dosis $0,75 \mathrm{mg} / \mathrm{liter}$, setiap perlakuan mendapat ulangan sebanyak 4 kali. Jenis pakan yang diberikan berupa cacing tubifex dengan 2 waktu pemberian di pagi (07.00) dan sore hari (15.00). Parameter yang diamati adalah sintasan, pertumbuhan (bobot dan panjang), uji proksimat serta kualitas air. Hasil penelitian menunjukan bahwa pengaruh pemberian dosis hormon tiroksin terhadap pertumbuhan (panjang dan bobot), sintasan benih ikan gurami terbaik diperoleh pada perlakuan 4 (D3), yaitu dengan dosis $0,75 \mathrm{mg} /$ liter dengan nilai pertumbuhan panjang $20,3 \pm 1,5 \mathrm{~mm}$, nilai pertumbuhan bobot $5,4 \pm 0,2$ gr dan kelangsungan hidup $0,88 \%$.
\end{abstract}

Kata Kunci : Gurami (Osphronemus gouramy), Tiroksin (T4), Sintasan. 


\section{PENDAHULUAN}

Ikan gurami (Osphronemus gouramy) merupakan salah satu komoditas perikanan air tawar yang memiliki nilai ekonomis tinggi dan prospektif untuk dikembangkan (Cahyono, 2000). Ikan ini banyak digemari masyarakat, karena memiliki citrarasa yang gurih dan khas, daging yang tebal, tekstur serat daging yang kesat (Lucas et al., 2015). Menurut Cahyono (2000) Ikan ini dikenal sebagai ikan yang lambat pertumbuhannya. Selanjutnya Susanto (1993) menambahkan bahwa ikan gurami selain lambat pertumbuhannya, pembudidaya masih kesulitan untuk menentukan pakan yang sesuai. Pada konteks ini, diperlukan penelitian lanjut dan studi pengembangan budidayanya.

Penggunaan teknik rekayasa hormonal merupakaan salah satu cara yang dapat dilakukan untuk memperbaiki kualitas pengembangan kultivasi beberapa ikan air tawar termasuk ikan gurami (Alwi et al., 2014). Beberapa hormon yang telah diketahui memiliki peranan positif dalam meningkatkan pertumbuhan ikan antara lain hormon tiroksin $\left(\mathrm{T}_{4}\right)$ dan hormon pertumbuhan (growth homone) (Aqil, 2012).

Hormon tiroid mempunyai peranan penting di dalam pengaturan metabolisme, pertumbuhan, perkembangan pada ikan (Evans, 1993). Kemudian . Metty (1985) menjelaskan bahwa hormon tiroksin dapat mempengaruhi metabolisme, meningkatkan pertumbuhan dalam panjang dan bobot, memicu produksi growth homone $(\mathrm{GH})$, mempengaruhi pigmentasi, meningkatkan tingah laku ikan, menurunkan efisiensi fosforilasi dan meningkatkan aktivitas spesifik sistem enzim oksidasi.

Beberapa penelitian sebelumnya menunjukan bahwa pemberian hormon tiroksin dapat mempercepat pertumbuhan dan meningkatkan kelangsungan hidup ikan Koki (Sembiring et al., 2015), ikan gobi (Junior \& Raswin, 2004). Fitriana (2002) waktu perendaman yang efektif untuk meningkatkan pertumbuhan larva ikan gurami adalah 24 jam. Lestari (1994) bahwa perendaman larva ikan lele (Clarias griepunus) dalam larutan hormon tiroksin pada dosis 1,5 ppm merupakan dosis yang terbaik bagi pertumbuhan berat dan kelulusanhidupan sebesar 9,33\%. Kurniawan (2011) pengaruh pemberian hormon tiroksin terhadap benih ikan gurami dengan metode perendaman terhadap pertumbuhan mutlak dan pertumbuhan panjang mutlak terbaik pada dosis $1,5 \mathrm{mg} / 3$ liter dengan berat mutlak sebesar $1,11 \mathrm{gr}$, panjang mutlak sebesar $0.93 \mathrm{~cm}$, dengan laju pertumbuhan sebesar 2,9\% dan laju pertumbuhan panjangan sebesar 0,74\% dengan laju kelulusanhidupan sebesar $100 \%$.

Berdasarkan fungsi dapat meningkatkan aktivitas protease dan lipase pada saluran pencernaan meningkatkan metabolisme protein dan lemak dalam tubuh, mengaktivasi enzimenzim pencernaan dan lemak dalam tubuh, dapat meningkatkan laju metabolisme tubuh. Sehingga penelitian diarahkan untuk menguji efek penggunaan hormon tiroksin terhadap benih ikan gurami ukuran $\pm 1 \mathrm{~cm}$ dan bobot $\pm 0,5$ gr dengan dosis yang berbeda yaitu pada perlakuan $\mathrm{D}_{\mathrm{O}}$ dosis hormon tiroksin $0 \mathrm{mg} /$ liter yang berfungsi sebagai kontrol, $\mathrm{D}_{1}$ dosis hormon tiroksin $0,25 \mathrm{mg} /$ liter, $\mathrm{D}_{2}$ dosis hormon tiroksin $0,5 \mathrm{mg} / \mathrm{liter}, \mathrm{D}_{3}$ dosis hormon tiroksin $0,75 \mathrm{mg} / \mathrm{liter}$. 


\section{METODOLOGI}

Penelitian dilaksanakan selama 30 hari mulai tanggal 5 mei 2016 sampai dengan tanggal 3 Juni 2016 di Laboratorium Lingkungan dan Laboratorium Kimia Kampus Sekolah Tinggi Perikanan (STP) Jakarta.

Alat-alat yang digunakan dalam penelitian ini adalah toples sebagai wadah yang berbentuk tabung dari bahan polietilene (PE) dengan volume 5 liter sebanyak 12 unit yang dilengkapi aerasi di setiap akuariumnya, alat bantu berupa seser yang digunakan sebagai alat untuk memindahkan atau mengambil ikan, selang untuk menyipon atau membersihkan sisasisa pakan dari kotoran ikan dan corong cacing sebagai tempat penyimpanan cacing sebanyak 12 buah.

Bahan uji yang digunakan dalam penelitian ini adalah hormon tiroksin. Pakan alami yang diberikan berupa cacing sutra (Tubifex sp). Hewan uji yang digunakan benih ikan gurami (Osphronemus gouramy) yang berasal dari hasil produksi pembenihan di Pusat Pelatihan Mandiri Kelautan dan Perikanan (P2MKP) Mina Laksana yang beralamat Jl. Tamansari Kec. Cibeureum Kota Tasikmalaya Jawa Barat. Hormon tiroksin yang digunakan yaitu hormon tiroksin komersial bermerek dagang Thyrax yang di produksi PT. Organon Indonesia. Hormon tiroksin ini dapat diperoleh di Toko Obat dan Apotik. Setiap tablet Thyrax mengandung $100 \mathrm{mcg}$ atau setara dengan $0,1 \mathrm{mg}$ tiroksin. Persiapan media perendaman hormon tiroksin dilakukan dengan cara melarutkan tablet Thyrax ke dalam air tawar sesuai dosis masing-masing perlakuan. Benih ikan gurami pada setiap masing-masing perlakuan direndam dalam larutan tiroksin selama 24 jam, dengan dosis sesuai masingmasing perlakuan, kecuali perlakuan $\mathrm{D}_{0}$ sebagai kontrol tanpa melalui proses perendaman. Perlakuan $\mathrm{D}_{1}$ dosis $0,25 \mathrm{mg} /$ /iter, perlakuan $\mathrm{D}_{2}$ dosis $0,5 \mathrm{mg} / \mathrm{liter}$, Perlakuan $\mathrm{D}_{3}$ dosis 0,75 $\mathrm{mg} / \mathrm{l}$.

Penelitian ini menggunakan Rancangan Acak Lengkap (RAL) dalam satu faktor dengan empat perlakuan tiga kali ulangan. Sehingga jumlah suatu percobaan adalah 12 unit wadah pemeliharaan (Sudjana, 1991). Pemeliharaan dilakukan didalam ruang terkontrol. Perlakuan ini menggunakan perbedaan dosis hormon tiroksin. Perlakuan ini menggunakan perbedaan pemberian dosis hormoon tiroksin, yaitu perlakuan 1 (D0) sebagai kontrol atau tanpa pemberian hormon tiroksin, perlakuan 2 (D1) dengan dosis $0,25 \mathrm{mg} / \mathrm{liter}$, perlakuan 3 (D2) dengan dosis $0,5 \mathrm{mg} /$ liter dan perlakuan 4 (D3) dengan dosis $0,75 \mathrm{mg} / \mathrm{liter}$. Selama penelitian ini dilakukan pengamatan terhadap pertumbuhan (bobot dan panjang), sintasan, uji proksimat dan kualitas air (suhu, DO, $\mathrm{pH}$, amoniak dan nitrat).

\section{HASIL DAN PEMBAHASAN}

\section{Hasil}

\section{Pengamatan Uji Proksimat}

Berdasarkan hasil uji proksimat yang dilakukan selama penelitian, diketahui bahwa hari ke-0 pada masing-masing perlakuan memiliki nilai rata-rata individu tidak berbeda. Rata-rata kadar protein pada setiap perlakuan adalah $14,24 \%$, rata-rata kadar lemak sebesar $0,50 \%$ dan rata-rata kadar abu sebesar 2,00\%. Sedangkan pada pengujian hari ke-15 hingga hari ke-30 semua parameter uji seperti kadar protein, lemak, abu dan air mengalami peningkatan kandungan. Selengkapnya nilai uji proksimat dapat disajikan pada tabel 1 . 
Tabel 1. Uji Proksimat (\% berat kering)

\begin{tabular}{|c|c|c|c|}
\hline \multicolumn{5}{|c|}{ Hari Ke-0 } \\
\hline Perlakuan & Protein (\%) & Lemak (\%) & Abu (\%) \\
\hline $\mathbf{D}_{\mathbf{0}}$ & 14,24 & 0,50 & 2,00 \\
\hline $\mathbf{D}_{\mathbf{1}}$ & 14,24 & 0,50 & 2,00 \\
\hline $\mathbf{D}_{\mathbf{2}}$ & 14,24 & 0,50 & 2,00 \\
\hline $\mathbf{D}_{\mathbf{3}}$ & 14,24 & 0,50 & 2,00 \\
\hline \multicolumn{4}{|c|}{ Hari Ke-15 } \\
\hline Perlakuan & Protein (\%) & Lemak (\%) & Abu (\%) \\
\hline $\mathbf{D}_{\mathbf{0}}$ & 15,06 & 0,83 & 2,02 \\
\hline $\mathbf{D}_{\mathbf{1}}$ & 15,10 & 0,85 & 2,01 \\
\hline $\mathbf{D}_{\mathbf{2}}$ & 15,30 & 0,85 & 2,15 \\
\hline $\mathbf{D}_{\mathbf{3}}$ & 15,33 & 0,86 & 2,18 \\
\hline \multicolumn{5}{|c|}{ Hari Ke-30 } \\
\hline Perlakuan & Protein (\%) & Lemak (\%) & Abu (\%) \\
\hline $\mathbf{D}_{\mathbf{0}}$ & 15,88 & 0,85 & 2,05 \\
\hline $\mathbf{D}_{\mathbf{1}}$ & 15,95 & 0,84 & 2,06 \\
\hline $\mathbf{D}_{\mathbf{2}}$ & 16,24 & 0,83 & 2,27 \\
\hline $\mathbf{D}_{3}$ & 16,99 & 0,82 & 2,29 \\
\hline
\end{tabular}

\section{Pertumbuhan Panjang Mutlak}

Hasil pengukuran terhadap laju pertumbuhan panjang mutlak menunjukan bahwa nilai laju pertumbuhan panjang tertinggi diperoleh pada perlakuan $\mathrm{D}_{3}(0,75 \mathrm{mg} / \mathrm{liter})$ dengan pertumbuhan panjang $20,3 \pm 1,5 \mathrm{~mm}$, diikuti dengan perlakuan $\mathrm{D}_{2}(0,5 \mathrm{mg} / \mathrm{liter})$ dengan pertumbuhan panjang $19,3 \pm 1,5 \mathrm{~mm}$, selanjutnya perlakuan $\mathrm{D}_{1}(0,25 \mathrm{mg} / \mathrm{liter})$ dengan pertumbuhan panjang $17,0 \pm 1,0 \mathrm{~mm}$ dan nilai terendah diperoleh pada perlakuan $\mathrm{D}_{0}$ (kontrol) dengan pertumbuhan panjang $15,7 \pm 1,5 \mathrm{~mm}$. Selengkapnya nilai laju pertumbuhan panjang dapat disajikan pada gambar 1.

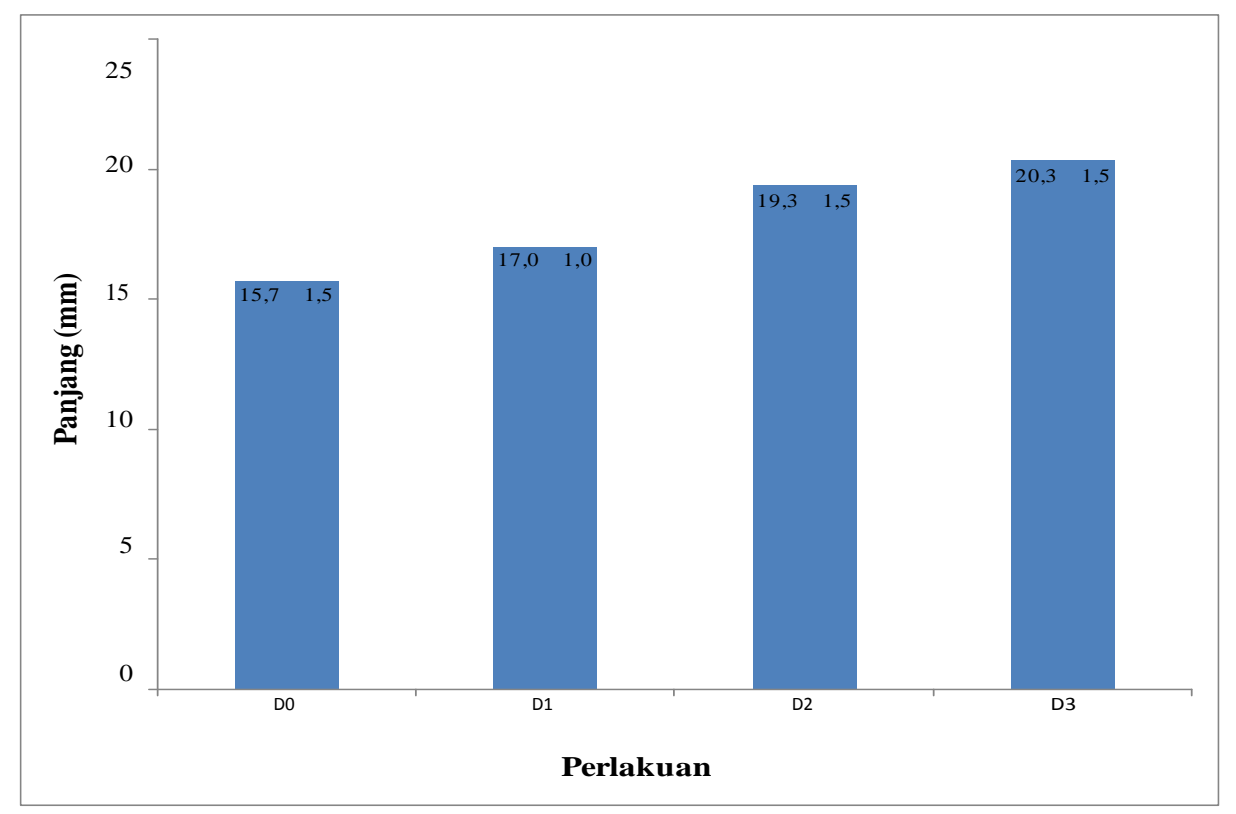

Gambar 1 : Grafik laju pertumbuhan panjang benih ikan gurami 


\section{Laju Pertumbuhan Bobot}

Hasil pengukuran terhadap laju pertumbuhan bobot menunjukan bahwa nilai laju pertumbuhan bobot tertinggi diperoleh pada perlakuan $\mathrm{D}_{3}(0,75 \mathrm{mg} / \mathrm{liter})$ dengan pertumbuhan panjang $5,4 \pm 0,2$ gr, diikuti dengan perlakuan $\mathrm{D}_{2}(0,5 \mathrm{mg} / \mathrm{liter})$ dengan pertumbuhan bobot 4,8 $\pm 0,2 \mathrm{gr}$, selanjutnya perlakuan $\mathrm{D}_{1}(0,25 \mathrm{mg} / \mathrm{liter})$ dengan pertumbuhan bobot $4,4 \pm 0,5$ gr dan nilai terendah diperoleh pada perlakuan $\mathrm{D}_{0}$ (kontrol) dengan pertumbuhan bobot 4,1 $\pm 0,6$ gr. Selengkapnya nilai laju pertumbuhan bobot dapat disajikan pada gambar 2 .

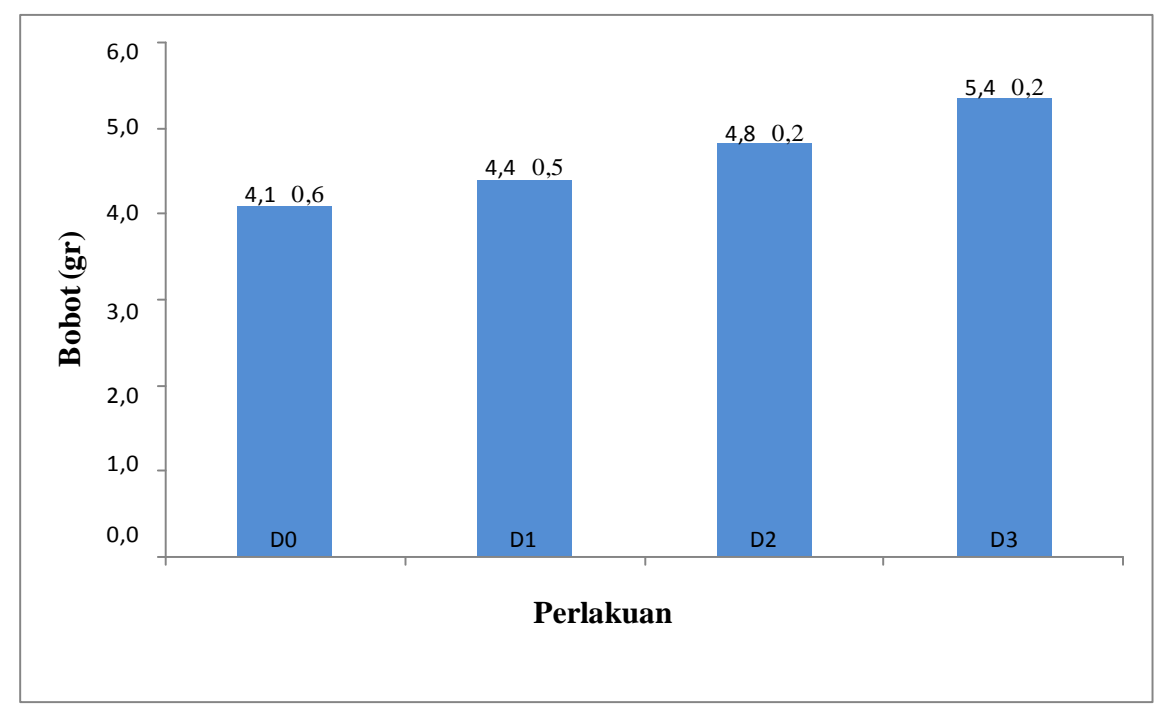

Gambar 2 : Grafik laju pertumbuhan bobot benih ikan gurami

\section{Kelangsungan Hidup}

Hasil pengamatan terhadap kelangsungan hidup menunjukan bahwa nilai kelangsungan hidup tertinggi diperoleh pada perlakuan $\mathrm{D}_{3}(0,75 \mathrm{mg} / \mathrm{liter})$ dengan nilai kelangsungan hidup $0,88 \pm 2,9 \%$, diikuti dengan perlakuan $\mathrm{D}_{2}(0,5 \mathrm{mg} /$ liter $)$ dengan nilai kelangsungan hidup $0,86 \pm 2,9 \%$, selanjutnya nilai kelangsungan hidup terendah diperoleh pada perlakuan $\mathrm{D}_{0}(0,5$ $\mathrm{mg} / \mathrm{liter})$ dan $\mathrm{D}_{1}(0,25 \mathrm{mg} / \mathrm{liter})$ dengan nilai kelangsungan hidup $0,85 \pm 8,7 \%$. Selengkapnya nilai kelangsungan hidup dapat disajikan pada gambar 3.

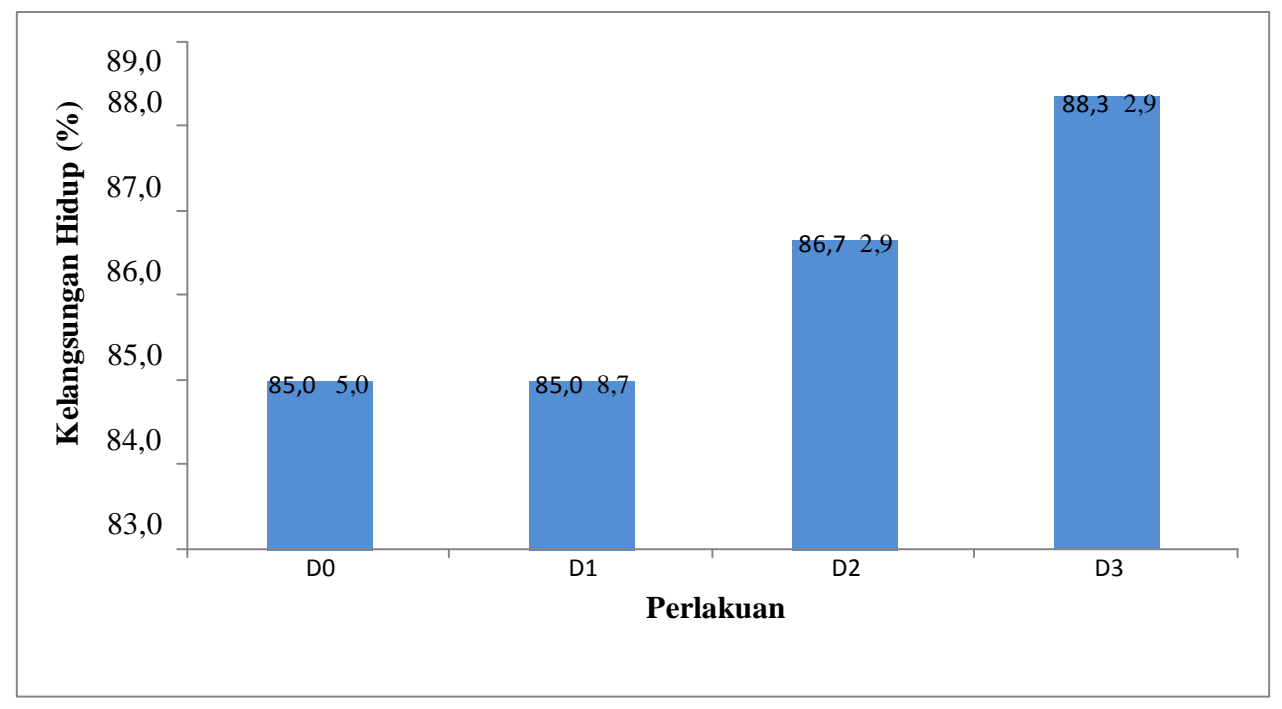

Gambar 3 : Grafik kelangsungan hidup benih ikan gurami 


\section{Pengamatan Kualitas Air}

Hasil pengamatan terhadap kualitas air menunjukan bahwa nilai suhu berkisar antara

$26,4-27,4{ }^{\circ} \mathrm{C}$, nilai DO berkisar antara 5,2 - 5,8 ppm, nilai pH berkisar antara 6,6 - 6,9, nilai amoniak berkisar antara $0,1-0,2 \mathrm{ppm}$ dan nilai nitrat berkisar antara $0,1-0,2 \mathrm{ppm}$. Untuk data hasil pengamatan parameter kualitas air disajikan pada tabel 2.

Tabel 2. Pengamatan Kualitas Air

\begin{tabular}{|l|r|r|r|r|r|}
\hline \multirow{2}{*}{ Parameter } & \multicolumn{4}{|c|}{ Perlakuan } & \multirow{2}{*}{ Standar Baku } \\
\cline { 2 - 5 } & \multicolumn{1}{|c|}{$\mathbf{D}_{\mathbf{0}}$} & \multicolumn{1}{c|}{$\mathbf{D}_{\mathbf{1}}$} & $\mathbf{D}_{\mathbf{2}}$ & $\mathbf{D}_{\mathbf{3}}$ & \\
\hline $\begin{array}{l}\text { Suhu } \\
\left({ }^{0} \mathrm{C}\right)\end{array}$ & $26,4-27,4$ & $26,4-27,4$ & $26,4-27,4$ & $26,4-27,4$ & $\begin{array}{c}24-28^{\circ} \mathrm{C} \\
(\text { Saparinto,2013) }\end{array}$ \\
\hline $\begin{array}{l}\text { DO } \\
(\mathrm{ppm})\end{array}$ & $5,3-5,7$ & $5,2-5,7$ & $5,3-5,7$ & $5,3-5,8$ & $\begin{array}{c}>4 \mathrm{mg} / \mathrm{liter} \\
(\text { Sunarya, 2005). }\end{array}$ \\
\hline pH & $6,7-6,8$ & $6,7-6,9$ & $6,6-6,9$ & $6,6-6,9$ & $\begin{array}{c}6,5-8,5 \\
(\text { Saparinto,2013) }\end{array}$ \\
\hline $\begin{array}{l}\text { Amoniak (NH3) } \\
(\mathrm{ppm})\end{array}$ & $0,1-0,2$ & $0,1-0,2$ & $0,1-0,2$ & $0,1-0,2$ & $\begin{array}{c}<0,2 \mathrm{mg} / \mathrm{liter} \\
(\text { Saparinto,2013) }\end{array}$ \\
\hline $\begin{array}{l}\text { Nitrat (No3) } \\
(\mathrm{ppm})\end{array}$ & $0,1-0,2$ & $0,1-0,2$ & $0,1-0,2$ & $0,1-0,2$ & $\begin{array}{c}<0,2 \mathrm{mg} / \text { liter } \\
(\text { Saparinto,2013) }\end{array}$ \\
\hline
\end{tabular}

\section{Pembahasan}

Hasil pengamatan yang dilakukan selama penelitian diperoleh data yang akan

menunjukan berpengaruh atau tidaknya pemberian perbedaan dosis hormon tiroksin yang diberikan terhadap pertumbuhan dan kelangsungan hidup benih ikan gurami. Hormon tiroksin yang diberikan pada benih ikan gurami melawati masa perendaman 24 jam disetiap perbedaan dosis yang diberikan. Hal ini sesuai dengan Fitriana (2002), dalam penelitiannya menyatakan bahwa lama waktu perendaman yang efektif untuk meningkatkan pertumbuhan benih ikan gurami adalah 24 jam.

Hasil pengujian uji proksimat tertinggi untuk kandungan protein dan abu pada hari ke 30 diperoleh pada perlakuan $\mathrm{D}_{3}(0,75 \mathrm{mg} / \mathrm{liter})$ dengan nilai kandungan protein $16,99 \%$, abu $2,29 \%$. Kemudian diikuti perlakuan $\mathrm{D}_{2}(0,5 \mathrm{mg} / \mathrm{liter})$ dengan kandungan protein $16,24 \%$, abu 2,27\%. Selanjutnya perlakuan $\mathrm{D}_{1}(0,25 \mathrm{mg} / \mathrm{liter})$ dengan kandungan protein 15,95\%, abu 2,06\%, dan terendah diperoleh pada perlakuan $\mathrm{D}_{0}$ (kontrol) dengan kandungan protein $15,88 \%$ dan abu 2,02\%. Namun sebaliknya untuk hasil pengujian uji proksimat tertinggi untuk kandungan lemak pada hari ke 30 diperoleh pada perlakuan $\mathrm{D}_{0}$ (kontrol) sebesar ,85\%, kemudian diikuti perlakuan $\mathrm{D}_{1}(0,25 \mathrm{mg} / \mathrm{liter})$ dengan nilai $0,84 \%$, selanjutnya perlakuan $\mathrm{D}_{2}(0,5 \mathrm{mg} /$ liter $)$ dengan $0,83 \%$ dan perlakuan $\mathrm{D}_{3}(0,75 \mathrm{mg} /$ liter $)$ dengan nilai $0,82 \%$. Untuk hasil data lapangan laju pertumbuhan panjang pada Gambar 1 terlihat nilai tertinggi terdapat pada perlakuan $\mathrm{D}_{3}(0,75 \mathrm{~g} / \mathrm{liter})$ 
dengan pertumbuhan panjang $20,3 \pm 1,5 \mathrm{~mm}$, diikuti dengan perlakuan $\mathrm{D}_{2}(0,5 \mathrm{mg} / \mathrm{liter})$ dengan nilai pertumbuhan panjang $19,3 \pm 1,5 \mathrm{~mm}$, selanjutnya perlakuan $\mathrm{D}_{1}(0,25$ $\mathrm{mg} /$ liter) dengan nilai pertumbuhan panjang $17,0 \pm 1,0 \mathrm{~mm}$ dan terendah pada perlakuan $\mathrm{D}_{0}$ (kontrol) atau tanpa diberikan hormon tiroksin dengan nilai pertumbuhan panjang $15,7 \pm 1,5 \mathrm{~mm}$.

Perlakuan $\mathrm{D}_{3}$ merupakan perlakuan pemberian hormon tiroksin dengan dosis tertinggi yaitu $0,75 \mathrm{mg} / \mathrm{liter}$. Sehingga nilai laju pertumbuhan panjang pada perlakuan tersebut lebih cepat dibandingkan dengan dosis yang lebih kecil, bahkan dengan perlakuan $\mathrm{D}_{0}$ atau tanpa pemberian hormon tiroksin. Hal ini disebabkan karena salah satu fungsi hormon tiroksin adalah mempercepat proses metabolisme secara umum dalam tubuh. Sebagaimana penjelasan Matty (1985), bahwa pemberian hormon tiroksin mempengaruhi peningkatan pertumbuhan dan metabolisme ikan. Dengan demikian diketahui mengapa pada perlakuan $\mathrm{D}_{0}$ atau tanpa pemberian hormon tiroksin mendapat nilai terendah dalam laju pertumbuhan panjang.

Pada perlakuan $\mathrm{D}_{2}(0,5 \mathrm{mg} / \mathrm{liter})$ merupakan perlakuan yang mendapat nilai tertinggi kedua sebesar 19,3 $\pm 1,5 \mathrm{~mm}$, diikuti dengan perlakuan $\mathrm{D}_{1}(0,25 \mathrm{mg} / \mathrm{liter})$ sebesar $17 \pm 1,5 \mathrm{~mm}$, hal tersebut diduga karena perbedaan dosis hormon tiroksin yang diberikan lebih kecil sehingga proses metabolismenya lebih lambat sehingga mempengaruhi laju pertumbuhan panjangnya. Namun hasil analisis keragaman melalui uji statistik menunjukan bahwa laju pertumbuhan panjang pada benih ikan gurami (Lampiran 1), diperoleh hasil $\mathrm{F}$ hitung $(6,819)$ lebih besar dari $\mathrm{F}$ tabel $(4,07)$ dengan taraf kepercayaan 95\%. Dengan demikian perbedaan pemberian dosis hormon tiroksin pada benih ikan gurami berpengaruh nyata terhadap laju

pertumbuhan panjang. Berbeda dengan Kurniawan (2011), yang menyatakan bahwa pengaruh pemberian hormon tiroksin dengan perendaman selama 10 hari terhadap pertumbuhan benih ikan gurami tidak nyata atau tidak berbeda nyata.

Selain pertumbuhan panjang ada pula pertumbuhan bobot atau penambahan massa pada tubuh ikan yang termasuk dalam katagori pertumbuhan pada tubuh ikan. Pada gambar 2 terlihat bahwa laju pertumbuhan bobot rata-rata individu benih ikan gurami dengan nilai tertinggi diperoleh pada perlakuan $\mathrm{D}_{3}(0,75 \mathrm{mg} / \mathrm{liter})$ dengan rata-rata bobot $5,4 \pm 0,2 \mathrm{gr}$, diikuti dengan perlakuan $\mathrm{D}_{2}(0,5 \mathrm{mg} /$ liter $)$ dengan nilai rata-rata bobot sebesar 4,8 $\pm 0,2 \mathrm{gr}$, selanjutnya diperoleh pada perlakuan $\mathrm{D}_{1}(0,25 \mathrm{mg} / \mathrm{liter})$ dengan nilai rata-rata bobot $4,4 \pm 0,5$ gr dan nilai rata-rata pertumbuhan bobot terendah diperoleh perlakuan $\mathrm{D}_{0}$ (kontrol) dengan nilai pertumbuhan $4,1 \pm 0,6$ gr.

Sama halnya dengan laju pertumbuhan panjang, nilai tertinggi yang diperoleh pada laju pertumbuhan bobot adalah perlakuan $\mathrm{D}_{3}(0,75 \mathrm{mg} / \mathrm{liter})$ dengan nilai $5,4 \pm 0,6 \mathrm{gr}$. Tidak lain karena pada perlakuan $\mathrm{D}_{3} \quad(0,75 \mathrm{mg} / \mathrm{liter})$ memiliki dosis terbesar dibandingkan perlakuan lainnya. Banyaknya jumlah dosis pada beberapa perlakuan mempengaruhi tingkat pertumbuhan pada tubuh ikan. Terlihat jelas pada gambar 2 yang menampilkan tingginya dosis pada perlakuan $\mathrm{D}_{3}$ menunjukan pertumbuhan bobot tercepat diikuti beberapa perlakuan lainnya hingga pemberian dosis terkecil, yaitu $\mathrm{D}_{2}$ dan $\mathrm{D}_{1}$ dan $\mathrm{D}_{0}$ tanpa pemberian hormon tiroksin. Dengan demikian besar-kecilnya dosis hormon tiroksin yang diberikan memberi pengaruh terhadap pertumbuhan pada tubuh benih ikan gurami.

Hal yang berbeda jika semua data laju pertumbuhan bobot dilihat menggunakan uji statistik. Hasil analisis keragaman melalui uji statistik menunjukan bahwa pengaruh 
pemberian perbedaan dosis hormon tiroksin pada benih ikan gurami (Lampiran 1) memperoleh hasil $F$ hitung $(5,482)$ lebih besar dari $F$ tabel $(4,07)$ dengan taraf kepercayaan 95\%. Dengan demikian pengaruh perbedaan pemberian dosis hormon tiroksin pada benih ikan gurami berbeda nyata terhadap laju pertumbuhan bobot. Berbeda dengan Kurniawan (2011), yang menyatakan bahwa pengaruh pemberian hormon tiroksin dengan perendaman selama 10 hari terhadap pertumbuhan benih ikan gurami tidak nyata atau tidak berbeda nyata. Djojosoebagio (1996) menyatakan bahwa ikan yang terlalu lama direndam hormon tiroksin mengakibatkan jumlah hormon tiroksin yang terserap oleh tubuh ikan tersebut melebihi kebutuhan fisiologis normal (hipertiroidisme). Dalam kondisi hipertiroidisme ini, metabolisme tubuh meningkat dengan sangat (hipermetabolik), sehingga biasanya ikan cenderung untuk selalu dalam keadaan kurus, karena seolah-olah ikan tersebut melakukan metabolisme terhadap sel-selnya sendiri.

Tidak berbeda dengan laju pertumbuhan panjang dan bobot, kelangsungan hidup atau sintasan benih ikan gurami juga diamati pengaruhnya atas perbedaan pemberian dosis hormon tiroksin. Jika dilihat pada gambar 3, nilai kelangsungan hidup tertinggi diperoleh pada perlakuan $\mathrm{D}_{3}(0,75 \mathrm{mg} / \mathrm{liter})$ dengan nilai persentase $88,3 \%$, diikuti perlakuan $\mathrm{D}_{2} \quad(0,5 \mathrm{mg} / \mathrm{liter})$ dengan nilai persentase $86,7 \%$ dan nilai terendah kelangsungan hidup benih ikan gurami diperoleh pada perlakuan $D_{1}(0,25 \mathrm{mg} / \mathrm{liter})$ dan $\mathrm{D}_{0}$ (Kontrol) dengan nilai persentase masing-masing 85\%. Dilihat dari nilai masingmasing persentase perlakuan, tingginya nilai persentase pada perlakuan $D_{3}(0,75 \mathrm{mg} / \mathrm{liter})$ diduga dipengaruhi dari besarnya pemberian dosis hormon tiroksin, diikuti dengan perlakuan $\mathrm{D}_{2}(0,5 \mathrm{mg} / \mathrm{liter})$ dan perlakuan $\mathrm{D}_{1}(0,25 \mathrm{mg} / \mathrm{liter})$.

Pemberian hormon tiroksin berfungsi dalam merangsang laju metabolisme umum pada benih ikan gurami. Dengan semakin baik metabolisme di dalam tubuh ikan maka selera makan akan meningkat, sehingga daya tahan tubuh ikan terhadap lingkungan semakin tinggi. Sebagaimana Lestari (1994) menyatakan bahwa tiroksin dapat meningkatkan pertumbuhan, perkembangan dan kelulushidupan serta mempercepat penyerapan kuning telur pada larva ikan nila. Dalam beberapa penelitian lain, penggunaan hormon tiroksin pada ikan memiliki pengaruh terhadap kelangsungan hidup. Seperti Lestari (1994) pada larva ikan lele dumbo dan Isvarida (2004) pada ikan baung.

Hasil analisis keragaman melalui uji statistik menunjukan bahwa pengaruh pemberian perbedaan dosis hormon tiroksin terhadap kelangsungan hidup benih ikan gurami (Lampiran

1) memperoleh hasil $F$ hitung $(0,26)$ lebih kecil dari $F$ tabel $(4,07)$ dengan taraf kepercayaan

95\%. Dengan demikian pengaruh perbedaan pemberian dosis hormon tiroksin pada benih ikan gurami tidak berbeda nyata terhadap kelangsungan hidup.

Berdasarkan hasil pengujian uji proksimat yang telah dilakukan terhadap ikan uji dapat diketahui persentase dari setiap komposisi nutrien diantaranya kandungan protein, lemak, abu dan air, untuk masing - masing hasil nilai uji proksimat dapat dilihat pada tabel 1. Pengujian uji proksimat selama penelitian dilakukan sebanyak tiga kali (hari ke 0 hari ke 15 dan hari ke

30).

Dengan demikian menunjukkan bahwa pada perlakuan $\mathrm{D}_{3}$ dengan kandungan hormon tiroksin tertinggi yaitu $0,75 \mathrm{mg} /$ liter mampu meningkatkan/merangsang laju metabolisme umum pada benih ikan gurami, semakin baik metabolisme di dalam tubuh ikan maka selera makan akan meningkat, sehingga daya tahan tubuh ikan terhadap lingkungan semakin tinggi. 
Hormon tiroksin akan lebih berfungsi optimal dalam mempengaruhi metabolisme tubuh bila didukung oleh kondisi lingkungan yang optimal. Diantaranya ketersedian oksigen terlarut yang mencukupi sangat diperlukan karena akan digunakan untuk proses metabolisme yang meningkat akibat pemberian hormon tiroksin.

Dalam proses penelitian ini, beberapa parameter kualitas air berada dalam keadaan yang sesuai dengan kondisi lingkungan yang optimum untuk ikan gurami, sehingga ikan uji tidak mengalami stres yang dapat mengganggu proses bekerjanya hormon tiroksin. Beberapa paremeter parameter yang terukur seperti suhu berkisar antara $26,4-27,4{ }^{\circ} \mathrm{C}$, nilai DO berkisar antara 5,2 - 5,8 ppm, nilai $\mathrm{pH}$ berkisar antara 6,6 - 6,9, nilai amoniak berkisar antara

$0,1-0,2 \mathrm{ppm}$ dan nilai nitrat berkisar antara 0,1-0,2 ppm.

\section{KESIMPULAN DAN SARAN}

\section{Kesimpulan}

Berdasarkan hasil penelitian diketahui bahwa pemberian hormon tiroksin dapat meningkatkan/merangsang laju pertumbuhan panjang, bobot dan menjaga kelangsungan hidup. Pemberian hormon tiroksin dengan dosis $0,75 \mathrm{mg} /$ liter merupakan dosis terbaik dalam meningkatkan pertumbuhan panjang, bobot dan menjaga kelangsungan hidup. Hal ini terlihat pada perlakuan $D_{3}(0,75 \mathrm{mg})$ dengan nilai pertumbuhan panjang $20,3 \pm 1,5 \mathrm{~mm}$, nilai pertumbuhan bobot 5,4 $\pm 0,2$ gr dan kelangsungan hidup $0,88 \%$.

\section{Saran}

Berdasarkan kesimpulan diketahui bahwa pemberian hormon tiroksin dengan dosis

0,75 mg/liter melalui perendaman selama 24 jam menunjukan hasil yang paling baik. Oleh sebab itu untuk mengetahui dosis yang optimal bagi pertumbuhan dan kelangsungan hidup benih ikan gurami, masih perlu dilakukan penelitian lanjutan dengan dosis dosis $0,55 \mathrm{mg} / \mathrm{liter}$ sampai $0,70 \mathrm{mg} / \mathrm{liter}$.

\section{DAFTAR PUSTAKA}

Alwi, D. A., Nasution, Z., \& Ramija, K. E. (2014). Pengaruh Pemberian Hormon Tiroksin Terhadap Pertumbuhan Dan Kelangsungan Hidup Ikan Black Ghost (Apteronotus albifrons). Aquacoastmarine, 5(4).

Aqil N. (2012) Efektifitas Perendaman Hormon Tiroksin dan Hormon Pertumbuhan Rekombinan Terhadap Keragaan Benih Ikan Patin Siam. Skripsi. Departemen Budidaya Perairan. Fakultas Perikanan dan IImu Kelautan. IPB. Bogor

Cahyono, I. B. 2000. Budi daya ikan air tawar: ikan gurami, ikan nila, ikan mas. Kanisius. Yogyakarta. 
Djojosoebagio, S. 1996. Fisiologi Kelenjar Endokrin.Universitas Indonesia. Jakarta.

Junior, M. Z., \& Raswin, M. M. 2004.Effectof Thyroxine Hormone Administrationin Female Broodstockon Metamorphosis and Survival Rates of Marble Goby (Oxyeleotrismarmorata,BLKR.) Larva. Jurnal Akuakultur Indonesia,3(3),5-8.

Kurniawan O. 2011. Pengaruh Pemberian Hormon Tiroksin $\left(\mathrm{T}_{4}\right)$ Dengan Perendaman Terhadap Pertumbuhan dan Kelangsungan Benih Ikan Gurami (Osphronemus gouramy Lac.). Skripsi. Fakultas Pertanian. Universitas Riau. Pekanbaru.

Lestari, M. 1994. Pengaruh Hormon Tiroksin $\left(\mathrm{T}_{4}\right)$ Terhadap Pertumbuhan dan KelulusanHidup Lele Dumbo (Clarias gariepinus). Skripsi. Perikanan dan Ilmu Kelautan. Universitas Riau. Pekan Baru.

Sembiring, D. R. N., Yusni, E., \& Lesmana, I.(2015). Pengaruh Pemberian Hormon Tiroksin Pada Pakan Terhadap Pertumbuhan Ikan Maskoki (Carrasius auratus). Journal Aquacoastmarine

Susanto, H. 1993. Budidaya Ikan di Pekarangan. Penabar Swadaya. Jakarta 